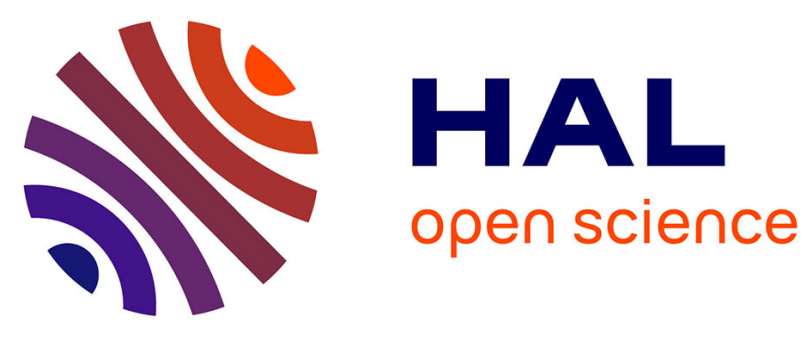

\title{
Origin And Distribution Of Polycyclic Aromatic Hydrocarbon Pollution In Sediment And Fish In The Biosphere'S Reserve Of Urdaibai (Bay Of Biscay, Basque Country, Spain)
}

Eunate Puy-Azurmendi, Asunción Navarro, Alba Olivares, Denise Fernandes, Elena Martínez, Miren López de Alda, Cinta Porte, Miren P. Cajaravilla, Damià Barceló, Benjamin Piña

\section{- To cite this version:}

Eunate Puy-Azurmendi, Asunción Navarro, Alba Olivares, Denise Fernandes, Elena Martínez, et al.. Origin And Distribution Of Polycyclic Aromatic Hydrocarbon Pollution In Sediment And Fish In The Biosphere'S Reserve Of Urdaibai (Bay Of Biscay, Basque Country, Spain). Marine Environmental Research, 2010, 70 (2), pp.142. 10.1016/j.marenvres.2010.04.004 . hal-00602603

\section{HAL Id: hal-00602603 https://hal.science/hal-00602603}

Submitted on 23 Jun 2011

HAL is a multi-disciplinary open access archive for the deposit and dissemination of scientific research documents, whether they are published or not. The documents may come from teaching and research institutions in France or abroad, or from public or private research centers.
L'archive ouverte pluridisciplinaire HAL, est destinée au dépôt et à la diffusion de documents scientifiques de niveau recherche, publiés ou non, émanant des établissements d'enseignement et de recherche français ou étrangers, des laboratoires publics ou privés. 


\section{Accepted Manuscript}

Title: Origin And Distribution Of Polycyclic Aromatic Hydrocarbon Pollution In Sediment And Fish In The Biosphere'S Reserve Of Urdaibai (Bay Of Biscay, Basque Country, Spain)

Authors: Eunate Puy-Azurmendi, Asunción Navarro, Alba Olivares, Denise Fernandes, Elena Martínez, Miren López de Alda, Cinta Porte, Miren P. Cajaravilla, Damià Barceló, Benjamin Piña

PII: S0141-1136(10)00055-3

DOI: 10.1016/j.marenvres.2010.04.004

Reference: MERE 3442

To appear in: Marine Environmental Research

Received Date: 30 October 2009

Revised Date: 6 April 2010

Accepted Date: 12 April 2010

Please cite this article as: Puy-Azurmendi, E., Navarro, A., Olivares, A., Fernandes, D., Martínez, E., de Alda, M.L., Porte, C., Cajaravilla, M.P., Barceló, D., Piña, B. Origin And Distribution Of Polycyclic Aromatic Hydrocarbon Pollution In Sediment And Fish In The Biosphere'S Reserve Of Urdaibai (Bay Of Biscay, Basque Country, Spain), Marine Environmental Research (2010), doi: 10.1016/ j.marenvres.2010.04.004

This is a PDF file of an unedited manuscript that has been accepted for publication. As a service to our customers we are providing this early version of the manuscript. The manuscript will undergo copyediting, typesetting, and review of the resulting proof before it is published in its final form. Please note that during the production process errors may be discovered which could affect the content, and all legal disclaimers that apply to the journal pertain. 
ORIGIN AND DISTRIBUTION OF POLYCYCLIC AROMATIC

HYDROCARBON POLLUTION IN SEDIMENT AND FISH IN THE

BIOSPHERE'S RESERVE OF URDAIBAI (BAY OF BISCAY, BASQUE

COUNTRY, SPAIN)

Eunate Puy-Azurmendi ${ }^{1}$, Asunción Navarro ${ }^{2}$, Alba Olivares ${ }^{2}$, Denise Fernandes ${ }^{2}$, Elena Martínez ${ }^{2}$, Miren López de Alda ${ }^{2}$, Cinta Porte ${ }^{2}$, Miren P. Cajaraville ${ }^{1}$, Damià Barcelón $^{2,3}$, Benjamin Piña, ${ }^{2, *}$

1) Laboratory of Cell Biology and Histology, Department of Zoology and Cell Biology, University of the Basque Country, B ${ }^{\circ}$ Sarriena, 48940 Leioa, Basque Country, Spain.

2) Institute of Environmental Assessment and Water Research (IDAEA-CSIC). Jordi Girona, 18. 08034 Barcelona, Spain.

3) Catalan Institute for Water Research (ICRA), Parc Científic i Tecnològic de la Universitat de Girona, Edifici Jaume Casademont, 15. 17003 Girona, Spain.

*) Author for correspondence: B. Piña, IDAEA-CSIC. Jordi Girona, 18. 08034

Barcelona, Spain. Tel: 3493400 6157; FAX: 3493204 5904; bpcbmc@cid.csic.es 


\begin{abstract}
The Urdaibai estuary is an UNESCO's biosphere reserve impacted by recreational, agricultural and industrial activities. Polycyclic aromatic hydrocarbons (PAHs) are major pollutants in Urdaibai, and their control and the identification of their sources is central on the preservation of the area. Chemical analysis by GC-MS showed a significant pollution by PAHs in Urdaibai sediment samples, mainly from pyrolytic sources, with minor contributions from oil spills. Measurement of the dioxin-like activity using a yeast-based bioassay showed an excess of biological activity in sediment samples from the inner part of the estuary. Analysis of PAH metabolites in bile of thicklip grey mullet (Chelon labrosus) showed a large excess of 2-naphthol over 1-naphthol or 1-pyrenol, suggesting a specific contamination in the inner Urdaibai estuary by some industrial process. Therefore, the combination of these three techniques defined different PAH pollution sources in Urdaibai: A major pyrolytic origin, occasional oil spills, and specific industrial activities.
\end{abstract}

Keywords: Dioxin-like activity, Recombinant yeast assay, GC/MS, PAH metabolites 


\section{Introduction}

The estuary of Urdaibai $\left(43^{\circ} 23^{\prime} \mathrm{N}-2^{\circ} 41^{\prime} \mathrm{W}\right)$ is located in the Bay of Biscay, in the Northern Iberian Peninsula (Figure 1). It is $13 \mathrm{~km}$ long and an average width of $500 \mathrm{~m}$, and presents a limited maritime traffic. The main human activity in the zone is agriculture but a variety of industries can be found such as metallurgic industries, shipyards, treatment of surfaces, dyes and manufacture of cutlery, concentrated in the surroundings of the main town in the area, Gernika-Lumo. Due to its unique landscape and to its good balance between human activities and the natural environment, it was declared a Biosphere's Reserve by UNESCO in 1984.

There are several environmental menaces looming over the Urdaibai ecosystem. Contamination by polycyclic aromatic hydrocarbons (PAHs) is of special concern, as they can been derived from both human activities (industrial byproducts, incomplete combustion of carburants) or from oil spills, either internal (shipping, carburant handling) or external. In this regard, massive oil spills, like the Prestige spill in 2002, are known to affect the estuary in the recent past (Cortazar et al., 2008; Orbea et al., 2006). Therefore, the continuous surveillance of PAHs pollution and the identification of its possible sources is central on the maintaining of the environmental health of the Urdaibai estuary. The present work addresses these issues using a combination of chemical analyses and bioassays directed to determine PAHs levels and composition in sediments, evaluate their biological activity, and analyze metabolites diagnostic for their origin and possible sources.

Due to their hidrophobicity, PAHs accumulate both in sediments and in the fat of exposed animals. They are considered hazardous for human health and a number of them are known carcinogenic compounds (Freire et al., 2009; IARC, 1983). PAHs constitute a very extended family of compounds, from which regulatory bodies have defined more or less comprehensive lists of priority compounds. The sixteen compounds listed by the US Environmental Protection Agency (EPA) or the eight ones included by the Water Framework Directive of the European Union (EU WFD) are used to define annual average and maximum allowable concentrations in surface waters (EC, 2008). In contrast, no comparable quality standards for sediments have been defined yet, despite of the tendency of these compounds to accumulate in hydrophobic compartments. In this work, we analyze the sixteen EPA PAHs along the Urdaibai estuary to identify areas of accumulation and to infer possible sources. 
The carcinogenic effect of different PAHs is a consequence of the ectopic up regulation of the oxidative metabolism in liver and other tissues from vertebrates. This effect is mediated by the binding of the pollutant to the aryl hydrocarbon receptor (AhR) (Gonzalez and Fernández-Salguero, 1998; Shimizu et al., 2000; van der Oost et al., 2003). The capacity of substances or environmental samples to activate the AhR system (the so-called dioxin-like activity, as dioxins are known to bind to AhR with extremely high affinity) can be quantified by a variety of aryl hydrocarbon-responsive reporter assays based on either in vivo animal tests (Willey et al., 1998) or different vertebrate cell lines (Villeneuve et al., 2002). Yeast-based bioassays represent a fast and cheaper alternative, although reports of their use for detection of AhR ligands in environmental samples are still scarce (Boronat et al., 2009; Lee et al., 2005; Murahashi et al., 2007). Yeasts lack AhR or any equivalent receptor, but their genetic make-up can be easily modified to reconstruct at least partially the mammalian pathway (Miller, 1999; Miller, 1997). In the present study we used a yeast strain expressing the human AhR and the cofactor ARNT to activate a reporter gene (ß-galactosidase) upon the presence of AhR ligands in the cell culture (Miller, 1997). In this genetic setup, the production of the reporter gene is diagnostic for the presence of AhR ligands in the medium, and can be quantified as an enzymatic activity with high precision (Noguerol et al., 2006a). With these tools, we determined AhR ligand activity in sediment samples from Urdaibai and compared these values with the observed chemical burden, to evaluate the importance of PAH pollution in the total toxicity of the sediments.

Fish living in PAH-contaminated environments absorb PAHs through the body surface and gills or by ingestion of contaminated sediment or food (Orbea et al., 2006; Raingeard et al., 2006; Varanasi et al., 1989). In this work, we assessed the exposure to PAHs in the thicklip grey mullet (Chelon labrosus, Mugilidae), a coastal fish present in eastern Atlantic Ocean and abundant in Urdaibai and other estuaries. This species is a good sentinel of human impact, as it feeds mainly on benthic diatoms, algae, small invertebrates and detritus. Direct measure of PAHs in tissues is impaired by the high capacity to metabolize and excrete PAHs of fish liver (Meador et al., 1995). Quantitation of PAHs excreted through the bile as conjugated metabolites is a suitable alternative to assess PAHs exposure in fish, both in the field and in laboratory experiments, since bile metabolites can easily be detected with high precision and sensitivity (Escartin and Porte, 1999; Fernandes et al., 2008a; Fernandes et al., 2002; Fernandes et al., 2008b; Yu et al., 1995). This methodology not only allows an 
estimation of the total PAH burden, but it also reveals information of the composition of this pollution, a central issue in the evaluation of the possible pollution sources.

\section{Materials and Methods}

\subsection{Study area and sample collection}

Surface sediment samples (one per site) were collected in April 2007, October 2007, and April 2008, in order to explore temporal trends, at six localities within the Urdaibai estuary, from its upstream limit to the mouth (Figure 1): Gernika, Murueta, Arteaga, Txatxarramendi, Mundaka and Laida. Murueta is a small town in the middle part of the estuary, where a medium size shipyard is placed. Arteaga is a small rural village, whereas Txatxarramendi is a small island in the outer part of the estuary. Mundaka is a small town in the mouth of the Oka River whose main activities are fisheries, agriculture and tourism. Laida is a beach at the mouth of the estuary, in front of Mundaka. For comparison purposes, sediments were also sampled in the leisure harbour of Arriluze, in the Abra estuary in the Basque Coast $\left(43^{\circ} 23^{\prime} \mathrm{N}-3^{\circ} \mathrm{W}\right.$, Figure 1), a site known by its high levels of pollution by PAHs (Cearreta et al., 2004). Surface sediment samples, collected in precleaned amber-glass bottles, were transported to the laboratory in refrigerated containers, and then frozen at $-20{ }^{\circ} \mathrm{C}$.

Fish (thicklip grey mullet Chelon labrosus) were sampled at approximately 1 $\mathrm{Km}$ distance from Gernika-Lumo urban center, near a sewage treatment plant, and in the Arriluze harbor, to compare PAH burden inside and outside Urdaibai. Six animals were captured in each site and campaign (36 animals in total). Fish were anaesthetized by immersion in a saturated solution of aminobenzocaine. Length $(29.5 \pm 5.5 \mathrm{~cm})$ and weight $(395.9 \pm 184.6 \mathrm{~g})$ of each fish were recorded, and the bile was taken, frozen in liquid nitrogen and stored at $-80^{\circ} \mathrm{C}$ until analysis.

\subsection{Analysis of PAHs in sediments}

Sediments samples were lyophilized during $48 \mathrm{~h}\left(10^{-2}\right.$ mbar vacuum) (Lioalfa, Telstar, Spain). The freeze-dried material was ground and homogenized using a mortar. Samples were sieved through 500 and $120 \mu \mathrm{m}$ mesh to obtain an homogeneous sediment material and stored in precleaned glass bottles at $-20{ }^{\circ} \mathrm{C}$ until extraction. Analysis of PAHs in the 
sediments was performed as described (Martinez et al., 2004). Sediment samples (1 g)

were extracted by ultrasonication with $3 \times 20 \mathrm{~mL}$ of a mixture of

hexane:dichloromethane $(1: 1)$, and the resulting extracts were cleaned-up by solid phase extraction (SPE) using neutral alumina, reconstituted in $250 \mu \mathrm{L}$ hexane, and analyzed of the resulting purified extracts by gas chromatography/mass spectrometry (GC/MS) with electron impact ionisation ( $70 \mathrm{eV})$ acquiring 3 characteristic ions per compound. Quantitation, based on peak areas, was performed by the internal standard method using surrogate deuterated standards. This method allows the determination of the 16 EPA PAHs at $\mathrm{ng} / \mathrm{g}$ levels (limits of detection between 0.1 and $2 \mathrm{ng} / \mathrm{g}$ ) with satisfactory precision (relative standard deviation calculated from 3 replicates below 20\%) and accuracy (recovery percentage above 50\% for all compounds except Naphthalene (20\%) and Benzo[g,h,i]Perylene (47\%). Analysis $(n=3)$ of a certified freshwater harbour sediment material (BCR535) within the sample sequence yielded concentrations matching the certified values with a percentage of error below $12 \%$.

Ratios of the PAH isomers Phenanthrene to Anthracene ( $\mathrm{Ph} / \mathrm{An})$, Fluoranthene to Pyrene (Fl/Py) and Benzo[a]Anthracene to Chrysene (BaA/Chrys) were calculated as indicators of $\mathrm{PAH}$ origin. Values of $\mathrm{Ph} / \mathrm{An}>50, \mathrm{Fl} / \mathrm{Pyr}<1$ and $\mathrm{BaA} / \mathrm{Chrys}<1$ are typical of samples of petrogenic (oil spill) origin, whereas the corresponding ratios of samples originated in combustion processes (pyrolytic) are typically $\mathrm{Ph} / \mathrm{An}<10, \mathrm{Fl} / \mathrm{Pyr}>1$ and BaA/Chrys $>1$ (Karacik et al., 2009; Poster et al., 2000; Webster et al., 2001).

\subsection{Recombinant yeast assay}

Aryl hydrocarbon receptor (AhR)-based recombinant yeast assays (AhR-RYA) were performed as previously described (Noguerol et al., 2006a; Noguerol et al., 2006b). The YCM1 yeast strain (Miller, 1997) was grown overnight in minimal medium (6.7 g/L) yeast nitrogen base without amino acids plus ammonium sulfate (DIFCO, Basel, Switzerland) supplemented with $0.1 \mathrm{~g} / \mathrm{L}$ of prototrophic markers as required and with galactose as a carbon source to express AhR and the cofactor ARNT (Miller, 1999). The final culture was adjusted to an optical density (OD) of 0.1 and split into $100 \mu \mathrm{L}$ aliquots in 96-well polypropylene microtiter plates (NUNC ${ }^{\text {TM }}$, Roskilde, Denmark; (Garcia-Reyero et al., 2001) previously silylated by overnight exposure to an atmosphere of dimethylsilane. We performed a serial dilution scheme based on 1:3 dilution steps and using glass microcapillary tubes rather than pipette tips for all liquid 
transfers, to eliminate contact with plastic surfaces (Garcia-Reyero et al., 2001). Plates were incubated for 4 hours at $30^{\circ} \mathrm{C}$ under mild shaking. After incubation, $100 \mu \mathrm{L}$ YPER $^{\mathrm{TM}}$ (PIERCETM, Rockford, IL, USA) were added to each well and further incubated at $30^{\circ} \mathrm{C}$ for $30 \mathrm{~min}$. Afterwards, $100 \mu \mathrm{L}$ of assay buffer supplemented with $0.1 \% 2$ - mercaptoethanol and $0.5 \%$ of the 4-methylumbelliferone $B-D-$ galactopyranoside (MuGal) solution (both from the FluorAce ${ }^{\mathrm{TM}}$ beta-galactosidase Reporter Assay Kit, Bio-Rad Laboratories, Hercules, CA, USA) were added to the lysed cells. After brief centrifugation, plates were read in a Victor3 Wallac spectrofluorometer (Perkin Elmer Inc., Wellesley, MA, USA), at 355nm excitation and 460nm emission wavelengths. Fluorescence was recorded for 15 to $20 \mathrm{~min}$ (one measurement per min); $B$ galactosidase activity values were calculated as rates of the increment of arbitrary fluorescence units with time, using standard linear regression methods. To test possible inhibitory activity (false negatives), yeast cultures were incubated for $4 \mathrm{~h}$ with $2 \mu \mathrm{M}$ of ß-naphthoflavone, added to a 1:30 dilution of each sample, and processed as before. No sample exhibited inhibitory activity high enough to significantly distort the results (not shown). In this particular system, the ratio of false positives is negligible (Miller, 1997; Noguerol et al., 2006a); several negative controls (wells with only vehicle plus yeast culture) were included in each plate. Samples were tested in triplicate. AhR-ligand activity values were calculated as naphthoflavone equivalents, NFEQ, defined as the concentration of B-naphthoflavone required to elicit the same response as the sample in the assay. These values were calculated from dose-response curves by adjusting $\beta$ galactosidase values to a first-order Hill equation, as described (Noguerol et al., 2006a), using at least 9 determinations for each value.

\subsection{Analysis of PAH metabolites in fish bile}

Hydroxylated PAH metabolites were analyzed by a modification of a previously described method (Escartin and Porte, 1999). Briefly, $100 \mathrm{mg}$ of bile (6 samples per area and sampling campaign) were incubated for $1 \mathrm{~h}$ at $40^{\circ} \mathrm{C}$ in the presence of $1 \mathrm{ml} 0.4$ $\mathrm{M}$ acetic acid/sodium acetate buffer $\mathrm{pH}$ 5.0, containing $2000 \mathrm{U}$ of $ß$-glucuronidase and $50 \mathrm{U}$ of sulfatase. Hydrolyzed metabolites were extracted with $1 \mathrm{ml}$ of ethyl acetate (x3), the extracts recombined and concentrated under a nitrogen stream. Dry residues of bile metabolites were then derivatized by the addition of $100 \mathrm{ml}$ of bis-(trimethylsilyl) trifluoroacetamide (BSTFA), heated for $1 \mathrm{~h}$ at $70^{\circ} \mathrm{C}$, and further reduced under a 
nitrogen stream. Analyses were carried by gas chromatography- mass spectrometry electron impact mode (GC-MS-EI) in a Fisons GC 8000 Series chromatograph interfaced to a Fisons MD800 mass spectrometer using a $30 \mathrm{~m}$ x $0.25 \mathrm{~mm}$ internal diameter HP-5MS column crosslinked with 5\% PH ME siloxane (Hewlett-Packard, USA). The instrument was programmed from $90^{\circ} \mathrm{C}$ to $140^{\circ} \mathrm{C}$ at $10^{\circ} \mathrm{C} \mathrm{min}^{-1}$ and from $140^{\circ} \mathrm{C}$ to $300^{\circ} \mathrm{C}$ at $4^{\circ} \mathrm{C} \min ^{-1}$, using helium at $80 \mathrm{kPa}$ as carrier gas. The injector temperature was $250^{\circ} \mathrm{C}$ and the ion source and the analyzer were maintained at $200^{\circ} \mathrm{C}$ and $250^{\circ} \mathrm{C}$, respectively. Just prior to sample analysis, calibration curves were performed with reference compounds and operating in selected ion monitoring mode (SIM). Hydroxylated-PAHs were identified by comparison of retention times and spectra of reference compounds. The silylation derivative ions used for monitoring and quantification of hydroxylated-PAHs were: $\mathrm{m} / \mathrm{z} 216$ and 201 for 1- and 2-naphthol; $\mathrm{m} / \mathrm{z}$ 254 and 165 for 9-fluorenol; $m / z 266$ and 251 for 9-phenanthrol; and $m / z 290$ for 1pyrenol. Recovery of extraction procedure was higher than $90 \%$ for all the compounds tested (1-naphthol, 9-fluorenol and 9-phenanthrol), except for 1-pyrenol which was 85\% (Escartin and Porte, 1999). Concentrations are expressed as nanograms per gram of bile.

\subsection{Statistics}

All statistical calculations, including linear and non-linear regression methods, were performed using the SPSS v. 17 package (SPSS Inc., Chicago, Ill.) Unless otherwise noted, significance levels were set at $\mathrm{p}<0.05$. Normality of distributions was tested with the Kolmogorov-Smirnov $\mathrm{Z}$ test. Most variables analyzed showed a non-normal distribution by the Z-test; therefore, non-parametric test were preferred. In cases in which parametric tests were required (e.g., ANOVA plus Tukey's test), they were performed using logarithmic transformants of the data, which followed a normal distribution with uniform variances for all categories tested (Z- and Levene's tests).

\section{Results and Discussion}

\section{1.- PAH levels in sediments}

Total PAH levels in Urdaibai sediments varied some 50-fold among sampling sites (Table 1, profiles in Figure 2A, bars). Except for Mundaka, which showed an extremely 
high variability, results from the three campaigns were similar for all sites, as revealed by K-means cluster analysis (Fig. 2B). The three sites at the inner part of the Urdaibai stuary showed similar, relatively low PAHs burdens, compared to Txatxarramendi and Arriluze sites (Figure 2). The two outer sites, Laia and Mundaka showed low PAH burdens comparable to those from the Urdaibai inner sites, except for the October 2007 sample from Mundaka, which we consider directly contaminated with oil (see next paragraph). A similar survey performed in years 2002-2004 recorded PAHs levels between 1,000 and $10,000 \mathrm{ng} / \mathrm{g}$, with some occasional samples largely exceeding these values (Cortazar et al., 2008). These results suggest that PAH levels remained essentially identical since at least 2002, suggesting a continuous, chronic contamination by PAHs, not necessarily linked to episodic oil spills.

Analysis of ratios between PAH isomers indicates a mainly pyrogenic origin of PAHs found in Urdaibai sediments (Table 1). 20 out of 21 samples showed $\mathrm{Ph} / \mathrm{An}$ ratios well below 10, indicative of a combustion process. Similarly, 14 out of 18 samples showed $\mathrm{BaA} / \mathrm{Chr}$ ratios over 1, also diagnostic of pyrogenesis (Karacik et al., 2009; Poster et al., 2000; Webster et al., 2001). In contrast, Fl/Pyr ratios below 1 shown by 11 out of the 21 samples suggest some contribution from oil spills (petrogenic) in at least some of them (Table 1). Petrogenic pollution, albeit never predominant, seemed to be more important in Gernika, Murueta and in the leisure harbor of Arriluze (Table 1), likely from seafaring and occasional oil spills from different sources. The October 2007 sample from Mundaka, which showed the highest PAH contents in all the series, is the only one with a $\mathrm{Ph} / \mathrm{An}$ ratio close to 50 , indicative of petrogenic origin (Table 1, Figures $2 \mathrm{~A}$ and $2 \mathrm{~B})$. We concluded that this particular sample may have been contaminated by an oil spill, probably a local one. With the exception of this particular sample, our results indicate that most PAHs found in Urdaibai and Arriluze have a pyrolytic origin, with a possible additional contribution of petrogenic hydrocarbons. Similar conclusion was reached in previous reports of PAH contents in Urdaibai sediments (Cortazar et al., 2008) and in the Istanbul Strait (Karacik et al., 2009), both showing PAHs levels and isomeric ratios similar to the ones observed in our study.

\subsection{AhR ligand activity in sediments}

All samples from Urdaibai sediments were positive for AhR ligand activity, indicating a general contamination by dioxin-like compounds (Figure 2). Maximal activities 
corresponded to Txatxarramendi and Arriluze sites, whereas minimal values were found in Mundaka and Laida sites (Figure 2, continuous line). Differences between samples collected at a given site during the three campaigns were relatively small (less than a factor of two), except for some few exceptions (Figure 2). K-means clustering of data clearly distinguished the two outer sites (Mundaka and Laia) as the ones with the lowest AhR-ligand activity, followed by the three Urdaibai inner sites (Gernika, Arteaga and Murueta). In the same analysis, Txatxarramendi appeared as the most contaminated site, surpassing even the Arriluze site (Figure 2B). The Abra estuary is much more heavily industrialised than the Urdaibai estuary, receiving considerable amounts of industrial, urban and agricultural untreated wastewater during about 150 years. Since 1980 a sewage treatment plant was set up and the environmental quality of the estuary started a recovery process (Gorostiaga et al., 2004), although levels of pollution by PAHs and other chemicals are still considered very high (Cearreta et al., 2004). Therefore, the presence in Urdaibai of a site with pollution levels similar to (if not even higher than) those from the Arriluze site, both in terms of chemical content and biological activity, argues for the requirement of a more strict control of pollution in the generally regarded as preserved Urdaibai estuary.

Comparison between AhR ligand activity and PAH burden profiles showed some significant similarities as well as differences. For example, both profiles show an increasing tendency from the innermost Urdaibai site, Gernika, to Txatxarramendi, close to the mouth of the estuary (Figures 2A and 2B, map in Figure 1). This last site showed values for both parameters comparable to the ones from the polluted Arriluze site in both profiles. In contrast, Mundaka and Laida showed a rather poor correlation between chemical and bioassay data, especially for the Mundaka site. In both cases, the observed low AhR ligand activity was at variance with their relatively high PAH burden. These discrepancies were diminished when the chemical data was converted to predicted dioxin-like activity, measured as TCDD equivalents (TEQ, Figure 2, discontinuous line), using relative effector potency (REP) values previously defined for AhR-RYA (Murahashi et al., 2007). By comparing the three profiles in Figure 2, we concluded that sediment samples from Mundaka and Laida were particularly poor in biologically active PAHs. This was particularly significant for the very highly polluted October 2007 Mundaka sample, which shows a very low biological activity. Conversely, most samples from the estuary, from Gernika to Txatxarramendi, may 
contain some unidentified AhR ligand to explain their higher-than-predicted dioxin-like activity in the AhR-RYA assay (Figure 2).

AhR ligand activity values showed strong positive correlation with the concentration of two groups of individual PAHs: The three-ringed Phenanthrene and Anthracene as one group and the four-ringed Benzo[a]anthracene, Benzo[b]fluoranthene, Benzo[k]fluoranthene and Benzo[a] pyrene as the second one (Table 2). Most of these compounds are known to bind the human AhR and to activate AhR-regulated genes, both in vitro and in vivo (Murahashi et al., 2007; Villeneuve et al., 2002; Willey et al., 1998). Consistently, we found a good correlation between AhRRYA results and the predicted TEQ values (Table 2). These results therefore indicate that a substantial fraction of the total AhR ligand activity present in Urdaibai sediments can be explained by their contents in the 16 EPA PAHs.

\subsection{PAH metabolites in fish bile}

Levels of PAH hydroxylated metabolites in bile of fish captured in Urdaibai and in Arriluze reflected the relative concentration of PAHs found in the sediments from both sites (Figure 3A). Fish collected in Arriluze showed values of PAHs metabolites in bile (734 - $4079 \mathrm{ng} / \mathrm{g}$ of bile) about three times higher than those from Gernika (283 - 1616 $\mathrm{ng} / \mathrm{g}$ ), although the variation between the three campaigns makes difficult to draw definite conclusions (Figure 3A). The general tendency for both sites was a decrease in OH-PAHs along the sampling seasons, however this decrease was more pronounced in Gernika, where the lowest levels of OH-PAHs were observed in April 2008 (Figure 3A). Metabolite profiles differed in both sites, suggesting different sources of PAHs. For example, 2-naphthol was the dominant PAH metabolite detected $(38-71 \%)$ in fish from Gernika, whereas in fish from Arriluze the major metabolite detected was of 1pyrenol (52-92\%) (Figure 3B). 1-Pyrenol is considered a key PAH metabolite in fish bile to monitor PAH exposure (Ruddock et al., 2002); consistently, its concentration in bile was significantly higher in fish from Arriluze than from Urdaibai (Mann-Whitney $\mathrm{U}$ test plus Bonferroni correction, $\mathrm{p}=0.001$ ). Conversely, levels of 2-naphthol were higher in Gernika than in Arriluze (Mann-Whitney U test plus Bonferroni correction, $\mathrm{p}<0.001$ ). Both 1-naphthol and 2-naphthol originate from naphthalene at very similar ratios through a 1,2 epoxy intermediate (Varanasi et al., 1989; Yang et al., 1999), and significant deviations on the concentrations of any of them are attributed to 
contamination from other sources unrelated to PAH metabolism, at least for human urine (Meeker et al., 2007; Serdar et al., 2003). Although it is possible that the ratios of synthesis and/or excretion of the two isoforms may differ between the two examined mullet populations, the almost 40-fold excess of 2-naphthol over 1-naphthol in the Gernika population (but not in the Arriluze population) argues for a specific contamination by some industrial process liberating 2-naphthol or a precursor substance. The fact that 2-naphthol made up to $70 \%$ of total biliar OH-PAHs in Gernika fish (Figure 3B) also argues for a specific source of this compound.

Biliary levels $\mathrm{OH}-\mathrm{PAHs}$ in grey mullet were 3 to 45 -fold higher than those detected in bile of Trisopterus luscus, a benthoplagic fish, collected along the inner shelf of the Basque Country coast (Fernandes et al., 2008a), suggesting a significantly higher anthropogenic pressure in the reserve of Urdaibai compared to the coastline. $\mathrm{OH}-$ PAHs levels found in grey mullet from Urdaibai were also similar or even higher than those detected in Mullus barbatus (91 - $1589 \mathrm{ng} / \mathrm{g}$ of bile) from the NW Mediterranean coast (Escartin and Porte, 1999). Direct comparison between different fish species is always difficult due to differences in habitat, metabolism and diet. This notwithstanding, the data suggest a significant contamination by PAHs in the Urdaibai endogenous fish population compared to the one observed in fish population from the coast, in line with our data on PAHs content and dioxin-like activity.

\subsection{General discussion and conclusions}

Sediments from Urdaibai showed a significant contamination by PAHs, particularly at the outer locality of Txatxarramendi. This site showed PAH levels comparable to those found in Arriluze, located in the neighbouring highly polluted Abra estuary. Blue mussels (Mytilus galloprovincialis) from Txatxarramendi show a high prevalence of oocyte atresia in developing or ripe bivalves (Puy-Azurmendi et al.), a condition that has experimentally been linked to the exposure to petroleum hydrocarbons (OrtizZarragoitia and Cajaraville, 2006). These results were a first indication that levels of PAHs and other pollutants in Urdaibai may be exceeding tolerance levels for at least some animal species.

The origin of PAHs in Urdaibai and Arriluze seems to be mainly pyrolytic, with some contribution of petrogenic sources in Gernika, Murueta and Arriluze. Comparison between chemical data with predicted and observed dioxin-like activity values defined 
different subsets of samples. Sampling points with strong marine influence, like

Mundaka and Laida, showed a low proportion of dioxin-like PAHs, although their total PAH burden was similar to (or even higher than) that of other samples with much stronger dioxin-like activity. Conversely, many samples from inside the estuary presented dioxine-like activity values higher than predicted by their content in PAHs, suggesting a contribution of dioxin-like compounds from other sources unrelated to PAH pollution. Finally, relative concentrations of 1-pyrenol, 1-naphthol and 2-naphthol in fish bile could indicate a specific industrial impact in Gernika relative to Arriluze, which may be related to the excess of dioxin-like activity observed in the inner Urdaibai samples. We conclude that PAHs are responsible for at least a substantial part of the AhR ligand activity we observed in the AhR-RYA assay, consistently with their property of being powerful AhR ligands. The substantial amounts of PAH metabolites found in bile of fish from Gernika and Arriluze confirms recent exposure to PAHs, although their actual physiological impact remains to be elucidated.

\section{Acknowledgements}

This work was supported by Catedra UNESCO of the University of the Basque Country (UPV/EHU) through the project DERBiUr (UNESCO06/19), by the Basque Government through the project ETORTEK-IMPRES and a grant to consolidated research groups (GIC07/26-IT-393-07), and by the Spanish Ministry for Science and Innovation (CGL2008-01898/BOS, CGL2007-64551/HID and Consolider-Ingenio 2010 CSD2009-00065). Denise Fernandes acknowledges a postdoc fellowship (SFRH/BPD/34289/2006) from the Portuguese Fundação para a Ciência e Tecnologia (FCT) of the Ministry of Science and Technology of Portugal.We greatly acknowledge the help of Dr. Maren Ortiz-Zarragoitia in coordinating the samplings and of all the students in the Laboratory of Cell Biology and Histology of the University of the Basque Country that participated in samplings. 


\section{References}

Boronat, S., Garcia-Reyero, N., Fonts, R., Fernández, P., Grimalt, J., Piña, B., 2009. Biological activity of aryl hydrocarbon receptor ligands in sediments from remote European lakes. Freshw. Biol. 54, 2543-2554

Cearreta, A., Irabien, M.J., Pascual, A., 2004. Human activities along the Basque coast during the last two centuries: geological perspective of recent anthropogenic impact on the coast and its environmental consequences, in: Borja, A., Collins, M. (Eds.), Oceanography and marine environment of the Basque Country. Elsevier BV, Amsterdam, The Netherlands, pp. 27-50.

Cortazar, E., Bartolome, L., Arrasate, S., Usobiaga, A., Raposo, J.C., Zuloaga, O., Etxebarria, N., 2008. Distribution and bioaccumulation of PAHs in the UNESCO protected natural reserve of Urdaibai, Bay of Biscay. Chemosphere 72, 14671474.

EC, 2008. Directive 2008/105/EC of the European Parliament and of the Council of 16 December 2008 on environmental quality standards in the field of water policy, amending and subsequently repealing Council Directives 82/176/EEC, 83/513/EEC, 84/156/EEC, 84/491/EEC, 86/280/EEC and amending Directive 2000/60/EC of the European Parliament and of the Council, in: Commun, O.J.E. (Ed.). European Parliament and Council, Brussels, pp. 84-97.

Escartin, E., Porte, C., 1999. Assessment of PAH pollution in coastal areas from the NW Mediterranean through the analysis of fish bile. Marine Pollution Bulletin 38, 1200-1206.

Fernandes, D., Andreu-Sanchez, O., Bebianno, M.J., Porte, C., 2008a. Assessment of pollution along the Northern Iberian shelf by the combined use of chemical and biochemical markers in two representative fish species. Environmental Pollution $155,327-335$.

Fernandes, D., Potrykus, J., Morsiani, C., Raldua, D., Lavado, R., Porte, C., 2002. The combined use of chemical and biochemical markers to assess water quality in two low-stream rivers (NE Spain). Environmental Research 90, 169-178.

Fernandes, D., Zanuy, S., Bebianno, M.J., Porte, C., 2008b. Chemical and biochemical tools to assess pollution exposure in cultured fish. Environmental Pollution 152, 138-146.

Freire, C., Abril, A., Fernandez, M.F., Ramos, R., Estarlich, M., Manrique, A., Aguirre, A., Ibarluzea, J., Olea, N., 2009. Urinary 1-hydroxypyrene and PAH exposure in 4-year-old Spanish children. Sci. Total Environ. 407, 1562-1569.

Garcia-Reyero, N., Grau, E., Castillo, M., López de Alda, M.J., Barceló, D., Piña, B., 2001. Monitoring of endocrine disruptors in surface waters by the yeast recombinant assay. Environ Toxicol Chem 20, 1152-1158.

Gonzalez, F.J., Fernández-Salguero, P., 1998. The aryl hydrocarbon receptor: studies using the AHR-null mice. Drug Metab Dispos 26, 1194-1198.

Gorostiaga, J.M., Borja, A., Díez, I., Francés, G., Pagola-Carte, S., Sáiz-Salinas, J.I., 2004. Recovery of benthic communities in polluted systems, in: Borja, A., Collins, M. (Eds.), Oceanography and marine environment of the Basque Country. Elsevier BV, Amsterdam, The Netherlands, pp. 549 - 578.

IARC, 1983. Polynuclear aromatic compounds, Part 1, chemical, environmental and experimental data, IARC monographs on the evaluation of the carcinogenicity risk of chemical to humans. International Agency for Research on Cancer, Lyon.

Karacik, B., Okay, O.S., Henkelmann, B., Bernhöft, S., Schramm, K.W., 2009. 
Polycyclic aromatic hydrocarbons and effects on marine organisms in the Istanbul

Lee, B.-C., Shimizu, Y., Matsuda, T., Matsui, S., 2005. Characterization of polycyclic aromatic hydrocarbons (PAHs) in different size fractions in deposited road particles (DPRs) from lake Biwa area, Japan. Environ. Sci. Technol. 39, 74027409.

Meador, J.P., Stein, J.E., Reichert, W.L., Varanasi, U., 1995. Bioaccumulation of polycyclic aromatic hydrocarbons by marine organisms. Rev Environ Contam Toxicol 143, 79-165.

Meeker, J.D., Barr, D.B., Serdar, B., Rappaport, S.M., Hauser, R., 2007. Utility of urinary 1-naphthol and 2-naphthol levels to assess environmental carbaryl and naphthalene exposure in an epidemiology study. Journal of Exposure Science and Environmental Epidemiology 17, 314-320.

Miller, C., 1999. A human aryl hydrocarbon receptor signaling pathway constructed in yeast displays additive responses to ligand mixtures. Toxicol. Appl. Pharmacol. 160, 297-303.

Miller, C.A., 3rd, 1997. Expression of the human aryl hydrocarbon receptor complex in yeast. Activation of transcription by indole compounds. J Biol Chem 272, 3282432829.

Murahashi, T., Watanabe, T., Kanayama, M., Kubo, T., Hirayama, T., 2007. Human aryl hydrocarbon receptor ligand activity of 31 non-substituted polycyclic aromatic hydrocarbons as soil contaminants. Journal of Health Science 53, 715721.

Noguerol, T., Boronat, S., Jarque, S., Barceló, D., Piña, B., 2006a. Detection of hormone receptor ligands in yeast by fluorogenic methods. TALANTA 69, 359358.

Noguerol, T.N., Boronat, S., Casado, M., Raldua, D., Barcelo, D., Pina, B., 2006b. Evaluating the interactions of vertebrate receptors with persistent pollutants and antifouling pesticides using recombinant yeast assays. Anal Bioanal Chem 385, 1012-1019.

Orbea, A., Garmendia, L., Marigomez, I., Cajaraville, M.P., 2006. Effects of the 'Prestige' oil spill on cellular biomarkers in intertidal mussels: results of the first year of studies. Marine Ecology-Progress Series 306, 177-189.

Ortiz-Zarragoitia, M., Cajaraville, M.P., 2006. Biomarkers of exposure and reproduction-related effects in mussels exposed to endocrine disrupters. Arch Environ Con Tox 50, 361-369.

Poster, D.L., De Alda, M.J.L., Wise, S.A., Chuang, J.C., Mumford, J.L., 2000. Determination of PAHs in combustion-related samples and in SRM 1597, complex mixture of PAHs from coal tar. Polycyclic Aromatic Compounds 20, 7995.

Puy-Azurmendi, E., Ortiz-Zarragoitia, M., Kuster, M., Martínez, E., Guillamón, M., Domínguez, C., Serrano, T., Barbero, M.C., Alda, M.L.d., Bayona, J.M., Barceló, D., Cajaraville, M.P., An integrated study of endocrine disruptors in sediments and reproduction-related parameters in bivalve molluscs from the Biosphere's Reserve of Urdaibai (Bay of Biscay). Marine Environmental Research In Press, doi:10.1016/j.marenvres.2009.10.003.

Raingeard, D., Cancio, I., Cajaraville, M.P., 2006. Cloning and expression pattern of peroxisome proliferator-activated receptor alpha in the thicklip grey mullet Chelon labrosus. Marine Environmental Research 62, S113-S117.

Ruddock, P.J., Bird, D.J., McCalley, D.V., 2002. Bile metabolites of polycyclic 
aromatic hydrocarbons in three species of fish from the Severn Estuary. Ecotoxicology and Environmental Safety 51, 97-105.

Serdar, B., Waidyanatha, S., Zheng, Y.X., Rappaport, S.M., 2003. Simultaneous determination of urinary 1-and 2-naphthols, 3-and 9-phenanthrols, and 1-pyrenol in coke oven workers. Biomarkers 8, 93-109.

Shimizu, Y., Nakatsuru, Y., Ichinose, M., Takahashi, Y., Kume, H., Mimura, J., FujiiKuriyama, Y., Ishikawa, T., 2000. Benzo[a]pyrene carcinogenicity is lost in mice lacking the aryl hydrocarbon receptor. Proc Natl Acad Sci U S A 97, 779-782.

van der Oost, R., Beyer, J., Vermeulen, N., 2003. Fish bioaccumulation and biomarkers in environmental risk assessment: a review. Environ Toxicol Pharmacol 13, 57149.

Varanasi, U., Reichert, W.L., Le Eberhart, B.T., Stein, J.E., 1989. Formation and persistence of benzo a pyrene-diolepoxide-DNA adducts in liver of English sole (Parophrys vetulus). Chem Biol Interact 69, 203-216.

Villeneuve, D.L., Khim, J.S., Kannan, K., Giesy, J.P., 2002. Relative potencies of individual polycyclic aromatic hydrocarbons to induce dioxinlike and estrogenic responses in three cell lines. Environ Toxicol 17, 128-137.

Webster, L., Fryer, R.J., Dalgarno, E.J., Megginson, C., Moffat, C.F., 2001. The polycyclic aromatic hydrocarbon and geochemical biomarker composition of sediments from voes and coastal areas in the Shetland and Orkney Islands. Journal of Environmental Monitoring 3, 591-601.

Willey, J.J., Stripp, B.R., Baggs, R.B., Gasiewicz, T.A., 1998. Aryl hydrocarbon receptor activation in genital tubercle, palate, and other embryonic tissues in 2,3,7, 8-tetrachlorodibenzo-p-dioxin-responsive lacZ mice. Toxicol Appl Pharmacol 151, 33-44.

Yang, M., Koga, M., Katoh, T., Kawamoto, T., 1999. A study for the proper application of urinary naphthols, new biomarkers for airborne polycyclic aromatic hydrocarbons. Arch Environ Con Tox 36, 99-108.

Yu, Y., Wade, T.L., Fang, J., McDonald, S., Brooks, J.M., 1995. Gas chromatographicmass spectrometric analysis of polycyclic aromatic hydrocarbon metbolites in Antartic fish (Notothenia gibberifrons) injected with diesel fuel Arch Environ Con Tox 29, 241-246. 
Figure Legends

Figure 1. Map of sampled sites. Sediment samples were collected at four localities inside the Urdaibai estuary (Gernika, Murueta, Arteaga and Txatxarramendi, detailed map on the right), Mundaka, at the river mouth, and Laida, outside the sand barrier limiting the estuary (grey areas in the detailed map). The leisure harbour of Arriluze, in the Abra estuary, was sampled as polluted external site. Fish were sampled only in Gernika and Arriluze. The approximate outline of the main city in Urdaibai, Gernika, is indicated with a discontinuous line at the bottom of the detailed map.

Figure 2. A) Profiles of EPA PAHs contents (bars, left axis), AhR-ligand activity in NFEQ (ß-naphthoflavone equivalents, calculated by YCM-RYA; continuous line, right axis) and predicted TEQ values (discontinuous line, arbitrary units) in sediment samples from 6 localities in Urdaibai and from Arriluze, taken during three consecutive campaigns. B) Value classification by K-means clustering (4 groups). Letters from "a" to "d" indicate samples belonging to statistically differentiated clusters ordered by increasing average (centroid) values; shadows of gray indicate the degree of pollution, from the cleanest cluster (white, labeled "a") to the most contaminated one (black, labeled "d").

Figure 3. A) Biliary levels of hydroxylated-PAHs detected in thicklip grey mullets collected in Gernika and Arriluze. Bars indicate total OH-PAHs content, SEM values are represented by lines. Letters correspond to homogeneous subsets of data (ANOVA plus Tukey's test, logarithmic transformants).

B) Relative contributions of different hydroxylated metabolites to the total hydroxylated-PAH contents in bile. Samples are identical to that of figure 3A. 


\begin{tabular}{|c|c|c|c|c|c|c|c|c|c|c|c|c|c|c|c|c|c|c|c|c|c|c|}
\hline \multirow[t]{2}{*}{ Area } & \multirow[t]{2}{*}{ Site } & \multirow[t]{2}{*}{$\begin{array}{c}\text { Sampling } \\
\text { date }\end{array}$} & \multirow{2}{*}{ 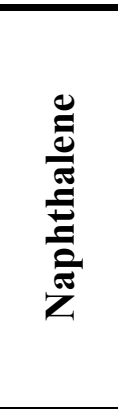 } & \multirow{2}{*}{ 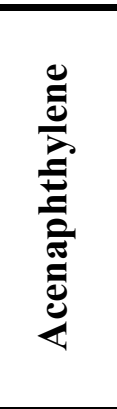 } & \multirow{2}{*}{ 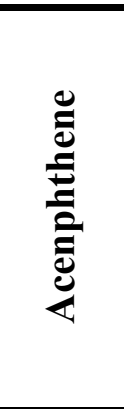 } & \multirow{2}{*}{ 离 } & \multirow{2}{*}{ 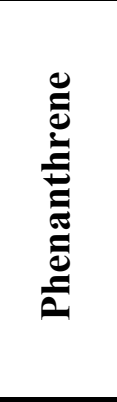 } & \multirow{2}{*}{ 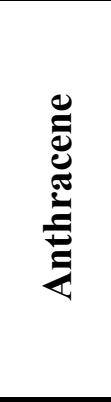 } & \multirow{2}{*}{ 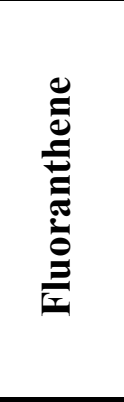 } & \multirow{2}{*}{ 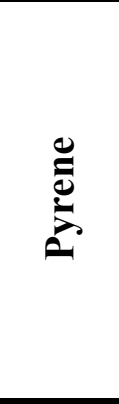 } & \multirow{2}{*}{ 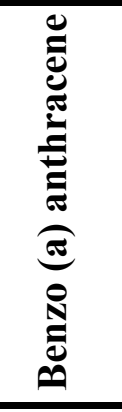 } & \multirow{2}{*}{ 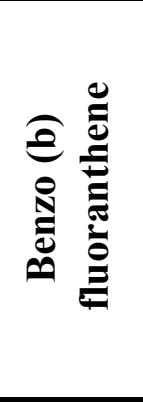 } & \multirow{2}{*}{ 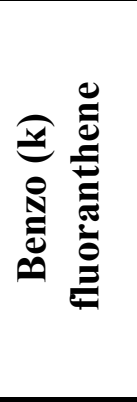 } & \multirow{2}{*}{ 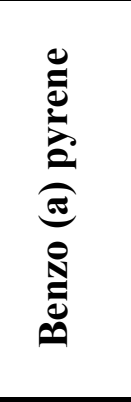 } & \multirow{2}{*}{ 总 } & \multirow{2}{*}{ 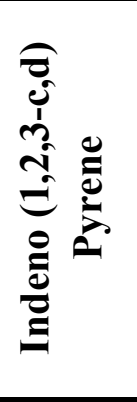 } & \multirow{2}{*}{ 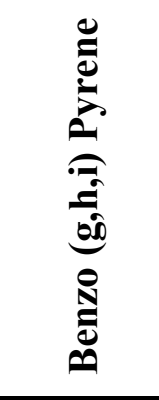 } & \multirow{2}{*}{ 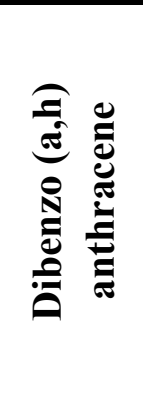 } & \multirow{2}{*}{ 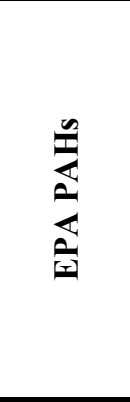 } & \multicolumn{3}{|c|}{ Isomer ratios $^{\mathrm{a}}$} \\
\hline & & & & & & & & & & & & & & & & & & & & Ph/An & F/Pyr & $\mathrm{BaA} / \mathrm{Cht}$ \\
\hline \multirow{9}{*}{ 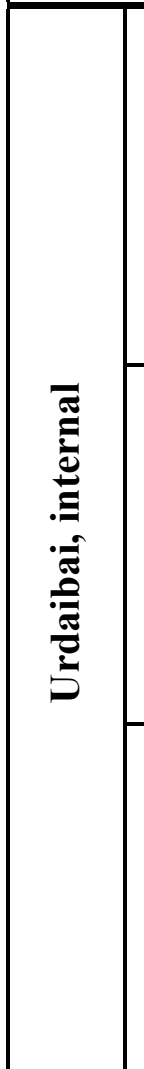 } & $\pi$ & Apr-2007 & 42 & 1.1 & 2.7 & 2.9 & 22 & 4.3 & 11 & 18 & 46 & 58 & 65 & 72 & 45 & 20 & 19 & 4.5 & 435 & 5.07 & 0.63 & 1.02 \\
\hline & 弟 & Oct-2007 & 214 & 2.0 & 4.1 & 5.0 & 152 & 58 & 47 & 78 & 232 & 294 & 340 & 296 & 283 & 60 & 61 & 4.7 & 2130 & 2.64 & 0.60 & 0.82 \\
\hline & & Apr-2008 & n.d & 305 & 3.1 & 322 & 264 & 79 & 13 & 34 & 449 & 552 & 346 & 345 & n.d & 441 & 15 & 40 & 3209 & 3.33 & 0.39 & \\
\hline & & Apr-2007 & 0.4 & 10 & 5.5 & 55 & 74 & 22 & 217 & 177 & 96 & 113 & 105 & 67 & 69 & 65 & 66 & 10 & 1153 & 3.32 & 1.22 & 1.39 \\
\hline & 㗙 & Oct-2007 & 0.5 & 13 & 6.9 & 8.5 & 111 & 33 & 137 & 149 & 187 & 208 & 240 & 149 & 167 & 99 & & & 1619 & 3.31 & 0.92 & 1.12 \\
\hline & & Apr-2008 & n.d & 154 & 4.5 & 155 & 156 & 57 & 42 & 103 & 318 & 384 & 173 & 166 & 118 & 502 & 122 & 301 & 2754 & 2.74 & 0.40 & 2.70 \\
\hline & $\tilde{g}$ & Apr-2007 & 66 & 805 & 38 & 6.7 & 62 & 19 & 18 & 22 & 114 & 133 & 114 & 71 & 74 & 66 & & 10 & 1687 & 3.24 & 0.82 & 1.55 \\
\hline & 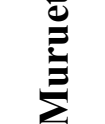 & Oct-2007 & 101 & 525 & 18 & 7.7 & 138 & 52 & 42 & 47 & 36 & 266 & 307 & 209 & 255 & & 101 & 11 & 2213 & 2.64 & 0.90 & 0.14 \\
\hline & & Apr-2008 & 304 & 181 & 3.3 & 145 & 237 & 92 & 38 & 110 & 424 & 528 & 165 & 232 & 35 & 712 & 68 & 98 & 3372 & 2.58 & 0.35 & 12.15 \\
\hline \multirow{9}{*}{ 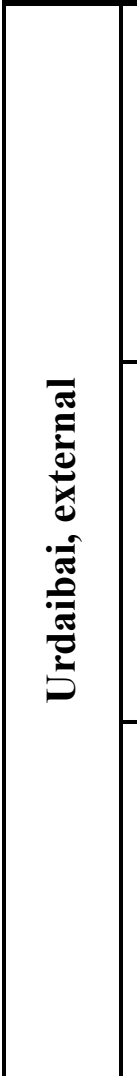 } & $\Xi$ & Apr-2007 & 102 & 615 & 11 & 126 & 611 & 227 & 1531 & 741 & 344 & 374 & 170 & 156 & 170 & 137 & 146 & 21 & 5482 & 2.69 & 2.07 & 2.03 \\
\hline & 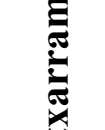 & Oct-2007 & 236 & 966 & 17 & 1187 & 487 & 188 & 1020 & 557 & 451 & 467 & 244 & 226 & 248 & 1679 & 185 & 23 & 8182 & 2.58 & 1.83 & 1.82 \\
\hline & 焉 & Apr-2008 & n.d & 1649 & 90 & 497 & 696 & 284 & 1070 & 972 & 1048 & 1188 & 338 & 474 & 100 & 1716 & 226 & 258 & 10607 & 2.45 & 1.10 & 10.52 \\
\hline & $g$ & Apr-2007 & 616 & 34 & 5.9 & 24 & 96 & 28 & 95 & 114 & 24 & 35 & 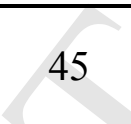 & 37 & 26 & 34 & 39 & 4.1 & 1257 & 3.42 & 0.84 & 0.95 \\
\hline & 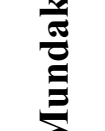 & Oct-2007 & 962 & 9100 & 609 & 551 & 560 & 13 & 2075 & 1552 & 283 & & 64 & 215 & 197 & 149 & 161 & 20 & 16778 & 42.35 & 1.34 & 1.44 \\
\hline & & Apr-2008 & 32 & 19 & 4.4 & 11 & 22 & 7.9 & 52 & 38 & 42 & 57 & 17 & 11 & 8.7 & 2035 & 1312 & 925 & 4593 & 2.72 & 1.34 & 4.88 \\
\hline & & Apr-2007 & 260 & 298 & 1286 & 125 & 10 & 45 & 160 & 160 & 41 & & 53 & 42 & 31 & 35 & 36 & 6.4 & 2634 & 0.22 & 1.00 & 1.33 \\
\hline & 蚫 & Oct-2007 & 147 & 1286 & 362 & 185 & 30 & 82 & 115 & 114 & 177 & 143 & 192 & 147 & 134 & 43 & 53 & 11 & 3222 & 0.36 & 1.01 & 1.33 \\
\hline & & Apr-2008 & n.d & 11 & 2.9 & 13 & 14 & 4.1 & 17 & 17 & 27 & 37 & 23 & 30 & n.d & 142 & n.d & n.d & 338 & 3.48 & 1.03 & \\
\hline \multirow{3}{*}{ 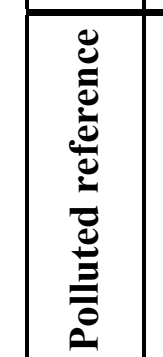 } & & Apr-2007 & 1002 & 164 & 84 & 240 & 799 & 281 & 683 & 640 & 817 & 724 & 786 & 597 & 457 & 393 & 498 & 53 & 8217 & 2.85 & 1.07 & 1.79 \\
\hline & 产 & Oct-2007 & 230 & 246 & 88 & 215 & 593 & 221 & 50 & 84 & 766 & 675 & 1322 & 887 & 1032 & 285 & 401 & 35 & 7129 & 2.68 & 0.59 & 0.74 \\
\hline & & Apr-2008 & n.d & 523 & 145 & 578 & 907 & 300 & 22 & 59 & 1958 & 2626 & 2082 & 1195 & n.d & 1135 & n.d & n.d & 11530 & 3.02 & 0.37 & \\
\hline
\end{tabular}


Table 2. Spearman's rank correlation between AhR-ligand activity and concentration of PAHs in Urdaibai samples

\begin{tabular}{|c|c|c|c|c|}
\hline & Rho & Sigma $^{a}$ & & $n$ \\
\hline Naphthalene & -0.306 & 0.249 & & 16 \\
\hline Acenaphthylene & 0.268 & 0.241 & & 21 \\
\hline Acenphthene & 0.134 & 0.563 & & 21 \\
\hline Fluorene & 0.269 & 0.239 & & 21 \\
\hline Phenanthrene & 0.647 & 0.002 & & 21 \\
\hline Anthracene & 0.549 & 0.010 & & 21 \\
\hline Fluoranthene & 0.171 & 0.457 & & 21 \\
\hline Pyrene & 0.225 & 0.328 & & 21 \\
\hline Benzo (a) anthracene & 0.636 & 0.002 & $* * *$ & 21 \\
\hline Benzo (b) fluoranthene & 0.622 & 0.003 & $* * *$ & 21 \\
\hline Benzo (k) fluoranthene & 0.565 & 0.008 & $* *$ & 21 \\
\hline Benzo (a) pyrene & 0.523 & 0.015 & * & 21 \\
\hline Chrysene & 0.422 & 0.081 & & 18 \\
\hline Indeno $(1,2,3-c, d)$ pyrene & 0.386 & 0.084 & & 21 \\
\hline Benzo $(g, h, i)$ perylene & 0.426 & 0.069 & & 19 \\
\hline Dibenzo $(a, h)$ anthracene & 0.263 & 0.276 & & 19 \\
\hline EPA PAHs & 0.342 & 0.130 & & 21 \\
\hline TEQ & 0.642 & 0.002 & $* * *$ & 21 \\
\hline
\end{tabular}

a) Two-tailed significance level. *, $\mathrm{p}<0.05 ; * *, \mathrm{p}<=.01 ; * * *, \mathrm{p}<0.005$ 

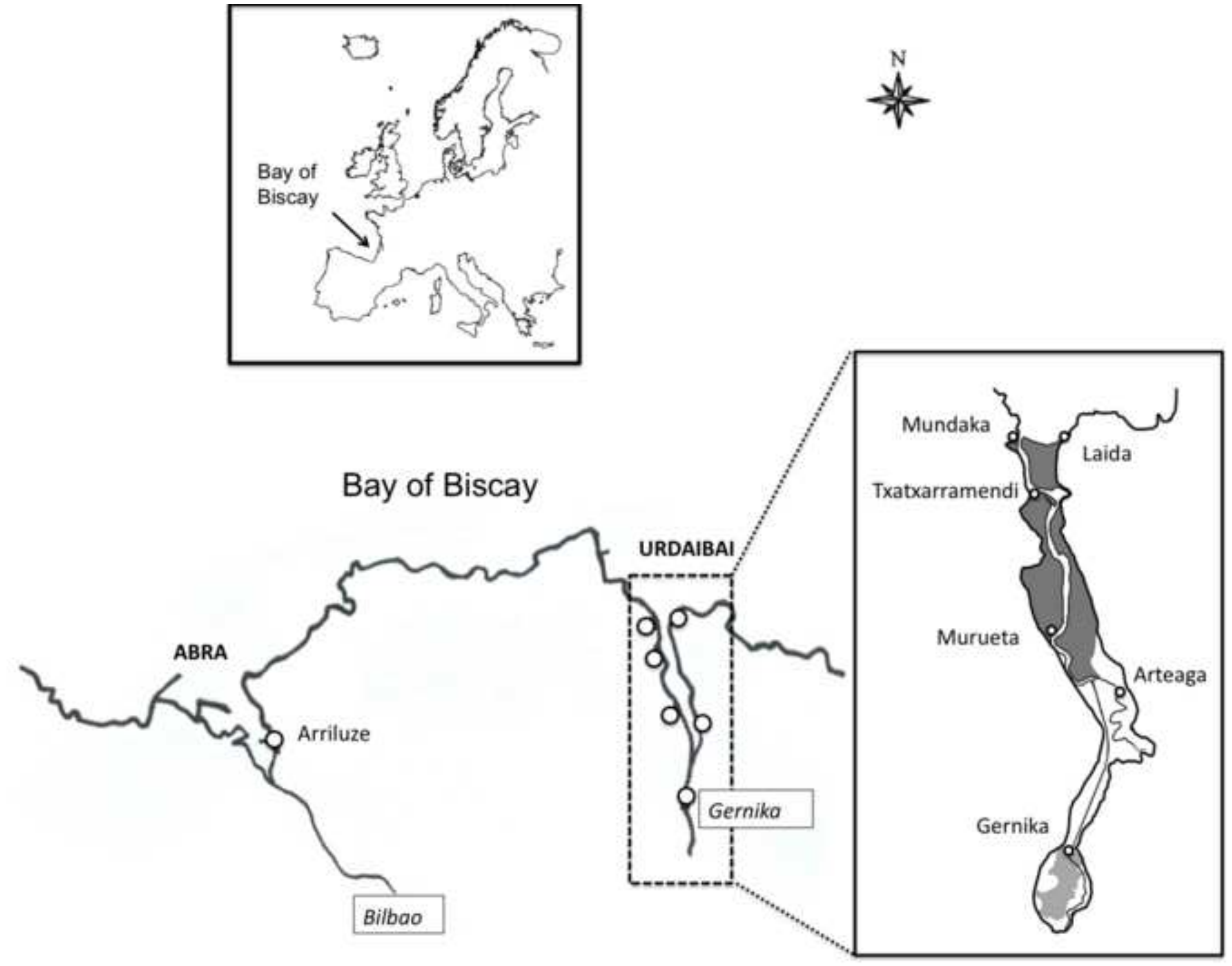


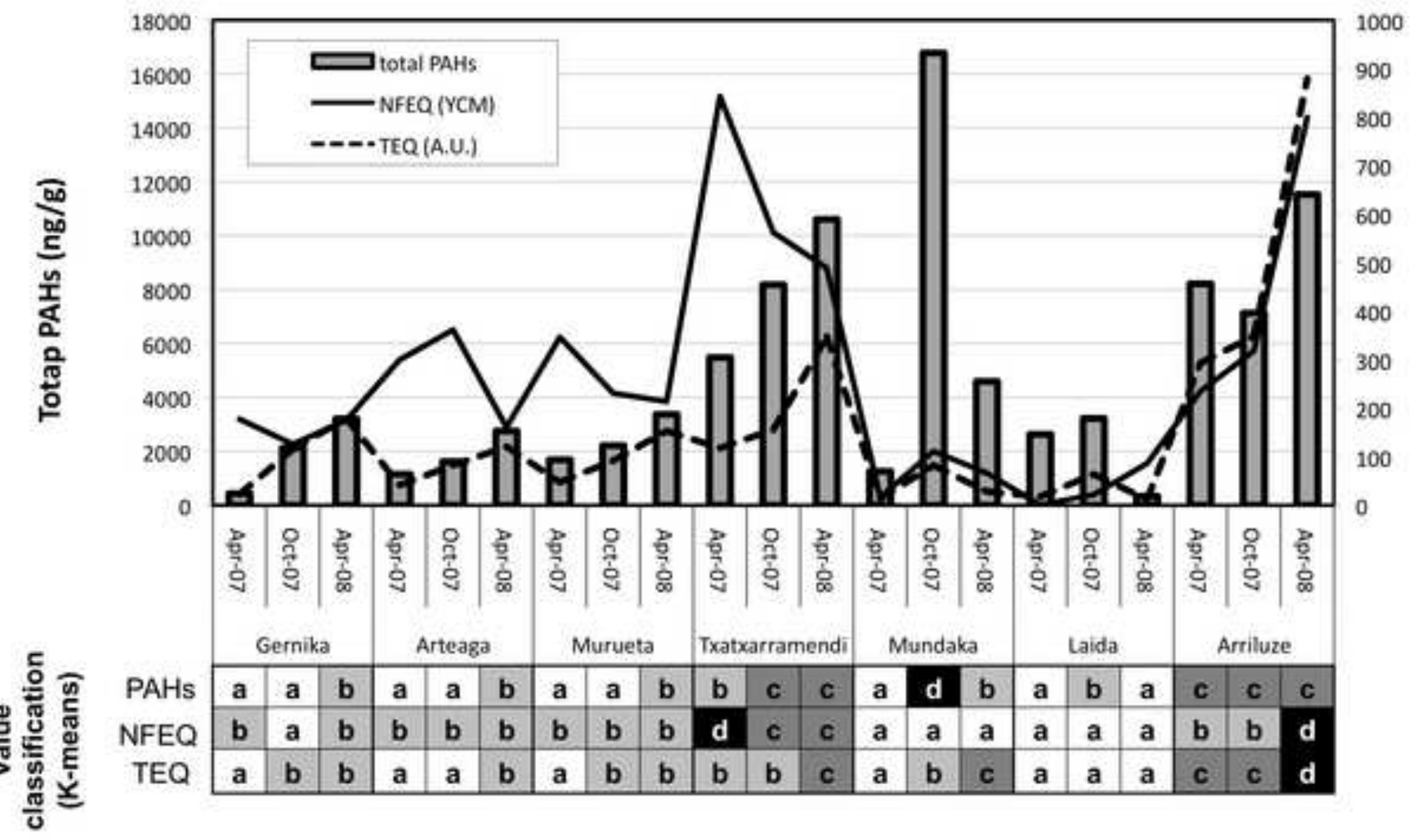

总 
Figure 3

Click here to download high resolution image ACCEPTED MANUSCRIPT

A

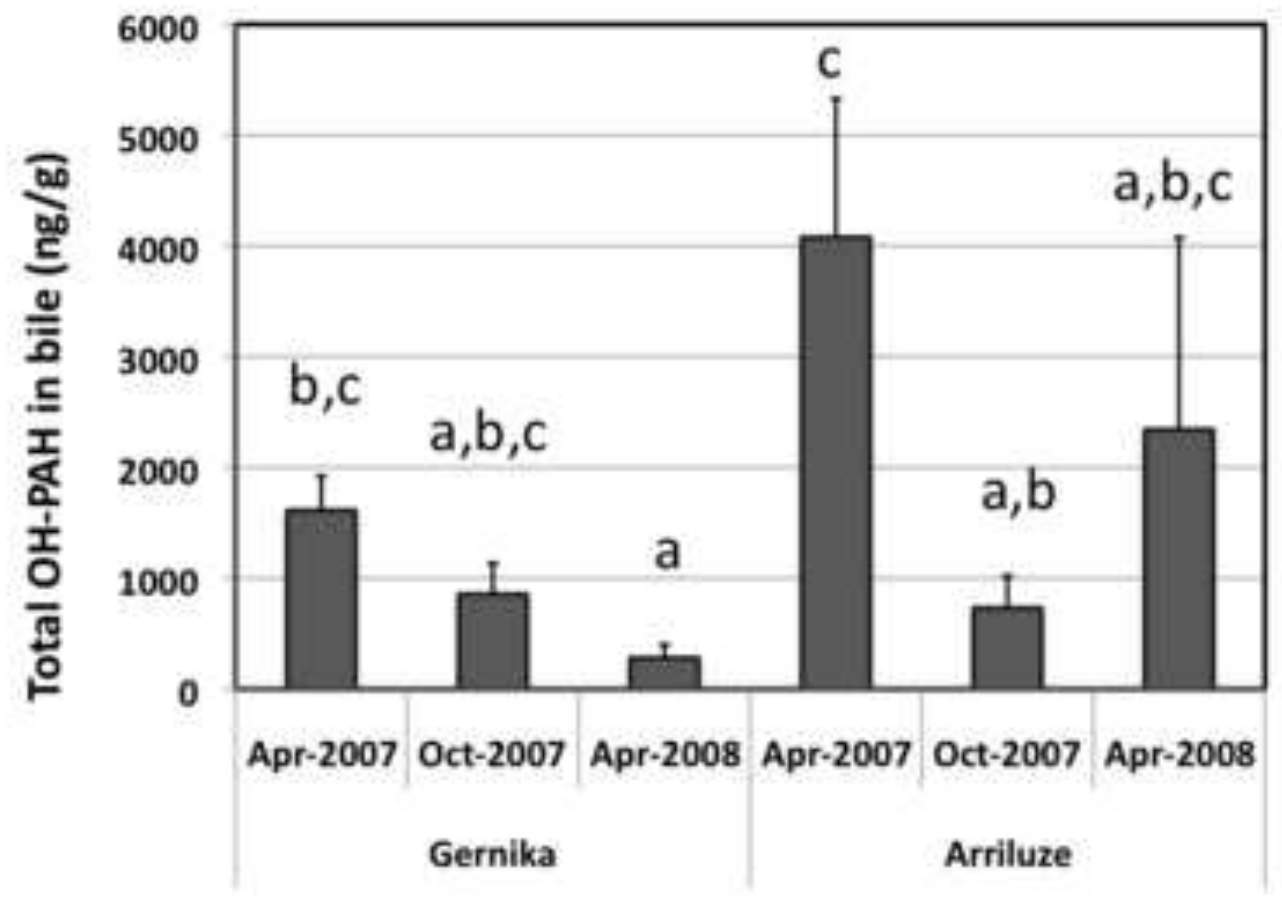

B

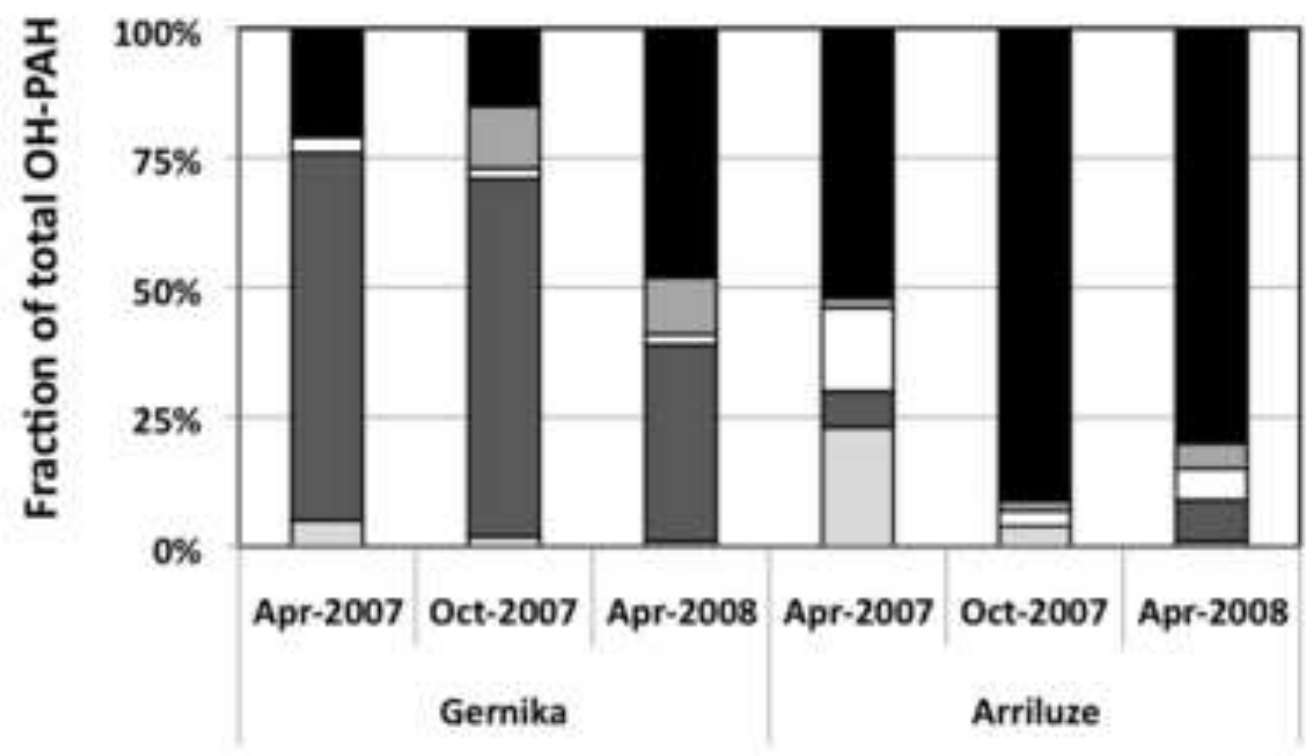

1-pyrenol a9-phenanthrol प9-fluorenol E2-naphthol 1-naphthol 